\title{
Development Modification for Handling, Storage and Transportation of chemicals in Textile plants located in southern India
}

\author{
Raj Pradeesh T, Venkumar P, Saravanamani M
}

\begin{abstract}
Wide ranges of chemicals are used at Water mill for its processes, which has its own intrinsic risks. It is necessary to implement safety practices and recommendations in chemical industry handling of organic products and hazards encountered due to storage of chemicals in industry. Due to these effects and consequences it may lead to the occupational diseases encountered, the various hazards are routes of entry through the human bodies Breath into lungs, Concentration through skin membrane/cuts in the skin, Assimilation via aperture into the digestive system and Cause potential harm to the environment in case of spillage/exposure. The works aims to frames the procedures and handling methods of chemicals inside the workplace. Water mill consists of chemicals having Corrosive, Irritant, Explosive, Flammable and Toxic in nature. Hence, employees have chance for exposure to chemical hazardous. To reduce the chemical hazards we need to take overview of the chemical handling and improve the storage and handling of chemicals.
\end{abstract}

Keywords- Handling, Hazard, Explosive, Storage, Transportation.

\section{INTRODUCTION}

There is some different type of chemical's are used in the Dying company. Thus the chemicals are used in different department like Cheese dying, Hank dying, Performance material and IBF these chemicals are highly hazardous liquids. Even a small spilling can be make a big explosion or disaster. To eliminate the hazards during handling of the chemicals in watermill and to improve storage of the chemicals. Ensure safe chemical handling processes in water mill. Base on improvements of chemical handling process. Safe work environment for employees will be ensured. Improving Work place safety. Reducing incidents on chemical handling, eliminating chemical hazards, unnecessary movement of chemicals.

Improvement of chemical handling process with the reference of S.P. Sivapirakasam. et al [1] states that the risk involved in chemical storage yards and usage of flash behaviors in pyrotechnics manufacturing process and identify the accidents in chemical handling areas. In Coats India watermill chemical handling is the key process in which employees have chance for exposure to chemical hazardous.

Revised Manuscript Received on December 5, 2019

* Correspondence Author

Raj Pradeesh T*, Department of Mechanical Engineering Kalasalingam Academy of Research and Education, Krishnankoil, India. Email: rajpradeesh29@gmail.com

Venkumar P, Department of Mechanical Engineering Kalasalingam Academy of Research and Education, Krishnankoil, India. Email: p.venkumar@klu.ac.in

Saravanamani M, Department of Mechanical Engineering Kalasalingam Academy of Research and Education, Krishnankoil, India. Email: saravanamani36@gmail.com
By improving the handling and storage systems work place hazards related to chemical will be controlled. Specific: Locations for Storage of chemicals, Handling of large quantity of chemicals, Transportation due to multiple locations. Measureable number of employees has exposure to chemical hazards. Agreed to: Improve the Chemical storage, Handling and transportation to reduce hazards to employees by recommending new methodology for handling of chemicals, proper containment and storage locations.

Watermill uses 7 Tons of Chemicals/Day for processes like cheese dyeing, hank dyeing and finishing operations for which around 200 employees where handling the chemicals who have prolong exposure to chemical hazards. Storage of chemicals done at 3 locations of Hank dyeing, 2 locations of cheese dyeing, 2 locations of performance material and 2 locations of finishing operations. Due to the storage of chemicals in more than one location for single operation requires movement of chemical during their usages, which create chance for spillage and other hazards during transportation. Chemical carboys are of different sizes from $25 \mathrm{~kg}$ to $200 \mathrm{~kg}$ whereas handling of the small quantity was easier and more difficulties faced during handling of the large quantity carboys, which create fall of the material, ergonomic hazards and spillage of chemical. To overcome the above-mentioned issues and to reduce hazards we are in need to improve system for storage, handling and transportation of the chemicals. At end of the project $100 \%$ elimination of the chemical hazards in the handling and storage will be ensured.

\section{LITERATURE REVIEW}

Most of the Top most and intermediate republic company employees and employers undergone to the risk and threats related to the exposure of the chemical impurities based on the material safety data sheets. Martel, B et al [6] The author reviewed the incident recall techniques is very prominent one for warning signs and material safety data sheets was very crucial one to develop the safety culture inside the workplace. Stellman, J. M et al [4] The literature reviewed, the number of techniques are available to develop the safety practices inside the organization based on the information available on the previous lesson learned incidents and chemical impurities data information's among the employee and employers of their corresponding companies. Steere, N. V et al [5]

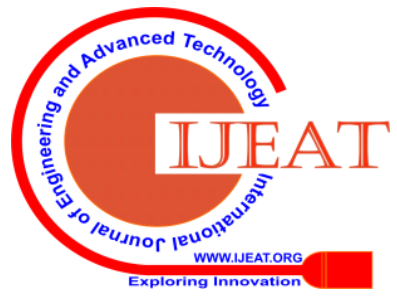



in southern India

This review represents the target studies conducted based on the experience of safety experts literacy levels and induction trainings carried by the safety experts and information from the graphical information's on the manual which they previously added by the employee and employers of various organizations. Olishifski, J. B et al . [7] This review has conducted in the chemical industry which mainly give that intention of the workers probably very high compherensive.The employer and employee of the company staffs are ready record their appropriate information related to the chemical handling and storage of chemicals. COATS INDIA Manual [8] The manual shows the outcome of the training requires the workers behaviors and realistic data like date of birth, male or female and literacy level of workers. The proof shows the ability of workers and identify their interest signaling actions and unit operations workers Health and Safety Guidelines-Act [9] breaches the works carried out incident recall techniques in chemical industry is very less compared to the other safety parameters. In olden researchers contributes only the few number of details that have been reviewed due to the insufficient methodology data's and procedure suggested by the authors. The review authors suggested to give more number of induction training to the workers regarding the incident recall techniques. Indian Standard (IS) 4209-1987 Code[10] refer identified the various data's shows the organization level that can be helpful to know their strength and weakness of the effective role of the experts that can be implemented the safety system inside the organization. Additional examination of the consequence of plan based causes on recollection should be scrutinized as well as trainings from dissimilar segments of the world to associate background transformations.

\section{III.METHODOLOGY}

\section{A.Fish Bone Analysis}

C-E diagram (Cause and Effect diagram) is an effective way to summarize and list various causes and root causes In C-E diagram, the most important thing is to show correlation between cause-effect, and all possible causality needs to be considered. Two ways of developing Fishbone diagram reference used Li Zhou et al [3] Tools used to identify the fishbone-picking lay out model for logistics and supply chain management process

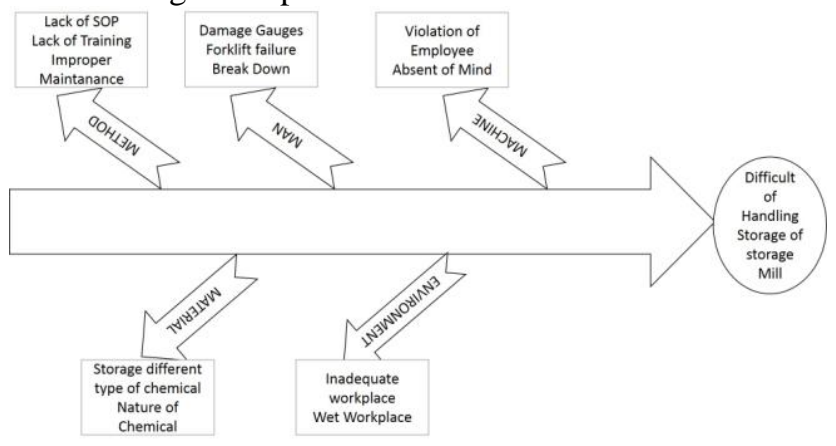

Fig. 1 Cause \& Effect Diagram for handling \& storage of chemicals

C-E diagram (Cause and Effect diagram) is an effective way to summarize and list various causes and root causes. In CE diagram, the most important thing is to show correlation between cause-effect, and all possible causality needs to be considered. Two ways of developing Fishbone diagram reference used Li Zhou et al [2] Tools used to identify the fishbone-picking lay out model for logistics and supply chain management process.

1. Put first level causes in main bones
2. Apply $5 \mathrm{M}+1 \mathrm{E}$ on main bones
- $\quad$ Men
- $\quad$ Method
- $\quad$ Measurement
- $\quad$ Environment
- Machine
B .Identification of Critical efficiency using fish-bone analysis

TABLE I: Estimation of Critical Efficiency

\begin{tabular}{|c|c|c|c|c|}
\hline \multirow{2}{*}{$\begin{array}{c}\text { VOB } \\
\text { ( Voice of the } \\
\text { Management) }\end{array}$} & \multirow{2}{*}{ Key issue } & \multicolumn{3}{|c|}{$\begin{array}{c}\text { CTB's } \\
\text { ( Critical to Efficiency) }\end{array}$} \\
\hline & & Frequency & $\begin{array}{c}\text { Formul } \\
\mathbf{a}\end{array}$ & Metric \\
\hline \multirow[b]{2}{*}{$\begin{array}{c}\text { Hazardous, } \\
\text { Flammable } \\
\text { chemical } \\
\text { handling, } \\
\text { storage, } \\
\text { transportatio } \\
\text { n. }\end{array}$} & \multirow[b]{2}{*}{$\begin{array}{l}\text { Safety } \\
\text { risk, Daily } \\
\text { process }\end{array}$} & Daily & $\begin{array}{c}\text { No of } \\
\text { movem } \\
\text { ent per } \\
\text { day \& } \\
\text { Type of } \\
\text { Chemic } \\
\text { al. }\end{array}$ & $\begin{array}{l}\text { No. \& } \\
\text { Liter }\end{array}$ \\
\hline & & Daily & $\begin{array}{c}\text { Chemic } \\
\text { al } \\
\text { movem } \\
\text { ent } \\
\text { distanc } \\
\text { e per } \\
\text { day \& } \\
\text { Distanc } \\
\text { e in } \\
\text { betwee } \\
\text { n } \\
\text { depart } \\
\text { ment. }\end{array}$ & meter \\
\hline $\begin{array}{l}\text { High labor } \\
\text { engaged in } \\
\text { chemical } \\
\text { handling, } \\
\text { transport. }\end{array}$ & Labor cost & Daily & $\begin{array}{c}\text { Total } \\
\text { labor } \\
\text { engage } \\
\text { d in } \\
\text { chemic } \\
\text { al } \\
\text { handlin } \\
\text { g/ } \\
\text { Total } \\
\text { labor } \\
\text { hours. }\end{array}$ & $\%$ \\
\hline $\begin{array}{l}\text { Number of } \\
\text { chemical } \\
\text { storage } \\
\text { location. }\end{array}$ & $\begin{array}{l}\text { Lack of } \\
\text { space. }\end{array}$ & Daily & $\begin{array}{l}\text { Type of } \\
\text { chemic } \\
\text { al (high } \\
\text { risk, } \\
\text { modera } \\
\text { te, low) }\end{array}$ & \\
\hline
\end{tabular}

C. Inference between Voice of the Management and critical factors: In the chemical handling process is hazardous, flammable process in storage and transporting inside of the industry. In the key issue is safety risk and daily process and the frequency is daily event.

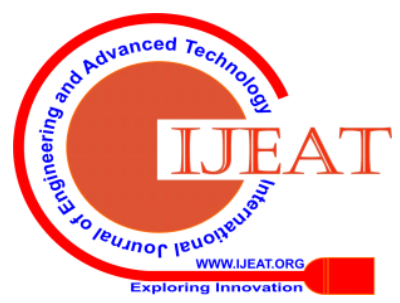


Thus the formula is number of movement per day and type of chemical and the metric scale is number and liter and the high labor engaged in the chemical handling process and transporting inside the industry if the key issue is labor cost on the process. And the frequency is daily event and the formula is total labor engaged in chemical handling and total labor hours/ cost in the metric measure is percentage. There is a huge of chemical used in the plant there is no adequate space in the store in the key issue is lack of space. In the process is daily process inside the company. Type of chemical (high risk, moderate, low) and the measurement is number with the reference of [3] Shen, J. K et al,2019 Examines the root causes of oil storage accidents and effects involved in industries.

\section{Handling Equipment and Method}

TABLE II: Handling Method of Chemical Equipment's In Storage Yard

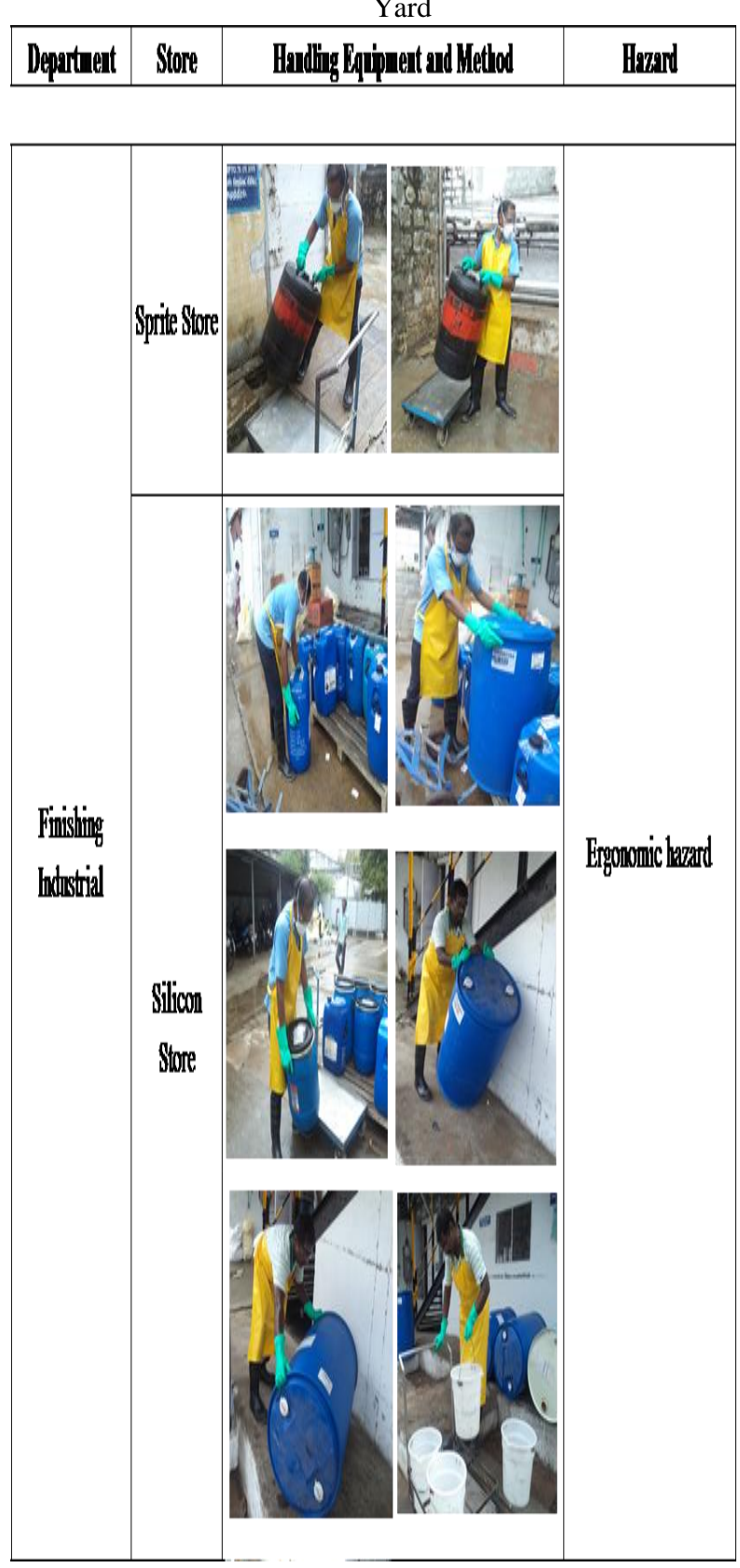

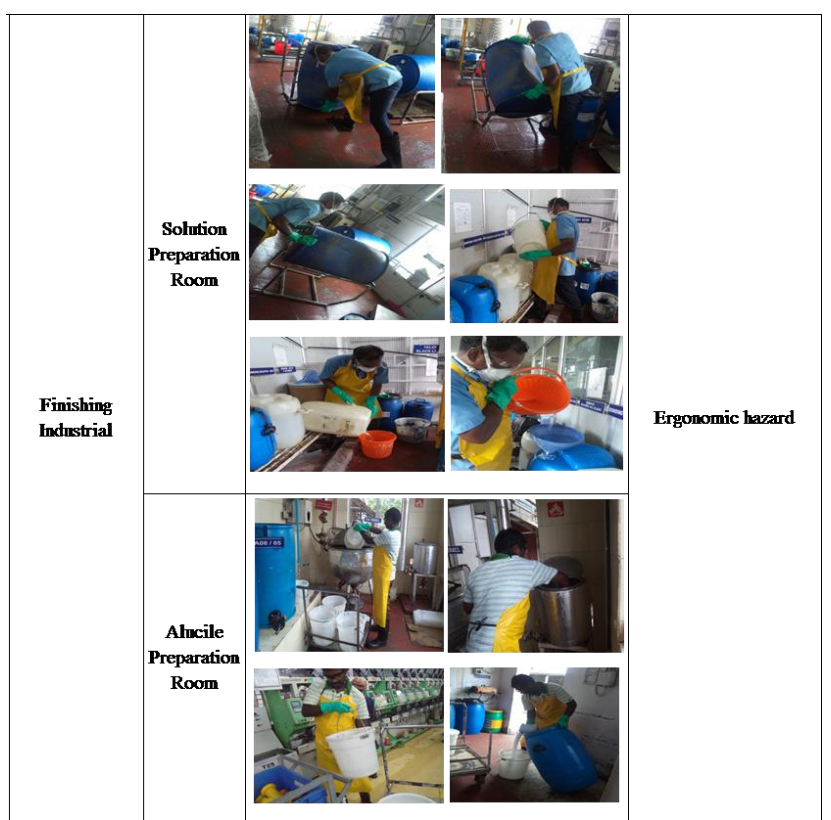

IV RESULTS AND DISCUSSIONS

The various process are clearly analysed in the manufacturing plants inside. All the activities are recorded manually and video graphically using the digital camera. The safety team form a committee entirely examine all the activities using hazard identification procedures and fish bone methods. All the inputs and outputs are analysed in same form. In this below activities are graphically viewed and their corresponding changes are given below. From the same practices are followed for the entire units and approval given by the safety manger report to the concern area supervisor for further changes are recorded.
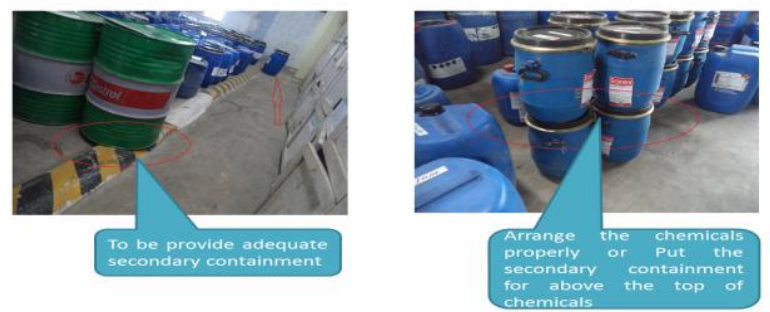

Fig 2 Improper Handling of chemicals using Tins
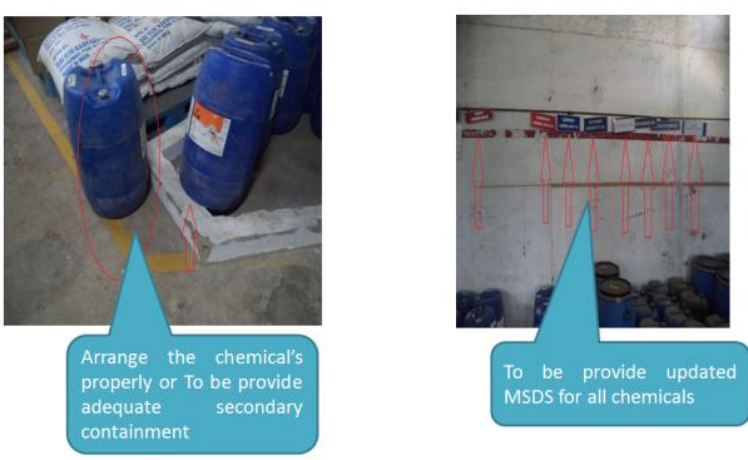

Fig 3 Arrangements of Chemicals with proper label

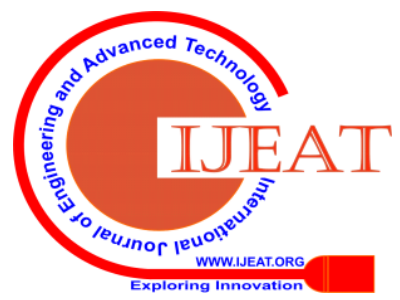



in southern India

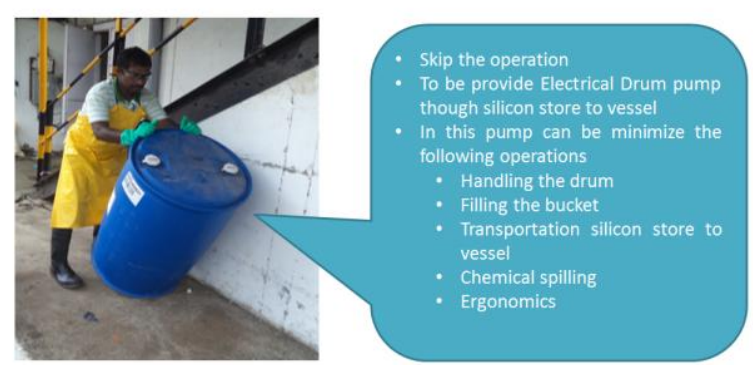

Fig 4 Manual Handling of Chemical using Tin

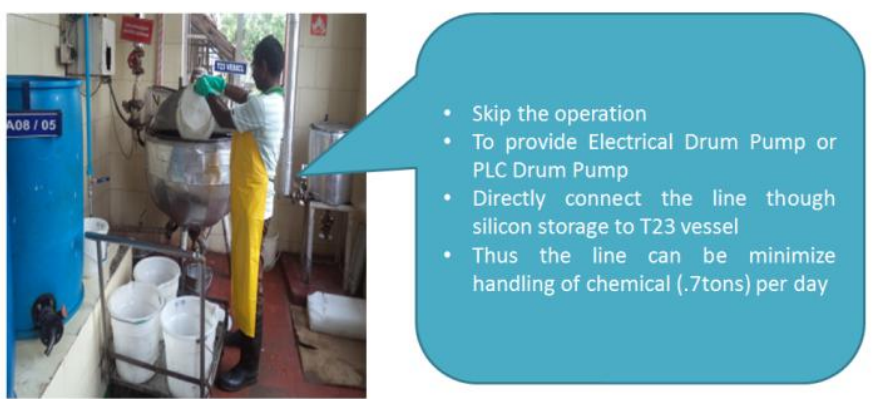

Fig 5 Handling of chemicals with proper precautions

\section{CONCLUSION}

Ensuring safety in handling, storage and transporting of chemicals needed to give more attention strategic plan to mitigate the explosion hazards while transporting the chemicals from one place to another. The EHS team and officer, Experts perform a special role in this field and take his/her response to handling the chemicals and storage. Adjustment with the handling, storage and transporting actions cannot create an individual satisfied near the hazards elaborate in the events. To avoid accidents in the handling, storage and transporting of chemicals in industry everybody has to be continuously attentive and yield practical determination in recognizing the dangers and realizing protective activities.

\section{FUTURE EXPANSION}

This modification evaluation method is applied in the textile industry to mitigate the chemical hazards exposed by the workers and handling methodology. In future the work can be further expanded to identify all type of hazrds encountred in textile industries and develop the modification changes for the current work and it will be detailed discussed about the potentual hazards. Also new methodoly tool can be used to predict the crtical type of hazards by aplying HIRA Tool or any HAZOP Study Techniques.

\section{REFERENCES}

1. S. P Sivapirakasam,., M Surianarayanan,., \& G.Swaminathan, "Hazard assessment for the safe storage, manufacturing and handling of flash compositions". Journal of Loss Prevention in the process industries, Vol.22(2),2009, 254-256.

2. L Zhou, Z. Li, N Shi, S Liu and K Xiong, "Performance Analysis of Three Intelligent Algorithms on Route Selection of Fishbone Layout". Sustainability, Vol.11(4),2019, 1148.

3. J. K Shen,., G. M Zhu,., M. Q.Zhang, , \& X. H Zhang,. "Safety Analysis and Countermeasure of Tank Car Transportation Based on Fish bone Diagram and Analytic Hierarchy Process". In IOP
Conference Series: Earth and Environmental Science Vol. 233, No. 3, 2019, p. 032023.

4. J. M. (Ed)Stellman "Encyclopaedia of occupational health and safety", International Labour Organization (Vol. 3), 1998.

5. N. V Steere," CRC handbook of laboratory safety" (No. 04; QD51, S8 1971.).

6. B.Martel," Chemical risk analysis: a practical handbook. Butterworth-Heinemann.Hazards in Chemical Laboratory"- G. D. Muir.2004.

7. J. B Olishifski, and F. E McElroy," Fundamentals of industrial hygiene. In Fundamentals of industrial hygiene". National Safety Council,1971

8. COATS INDIA - Madura Coats India Pvt. Ltd. ( Ambas )

9. Department of Health and Safety Guidelines-Act safe

10. Indian Standard (IS) 4209-1987 Code of Safety in Chemical Laboratories

\section{AUTHORS PROFILE}

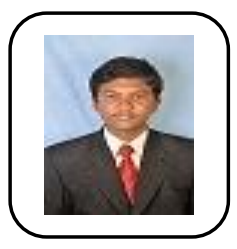

Rajpradeesh T Working as Assistant Professor at Kalasalingam Academy of Research \& Education. His research interest in the domain of Industrial Safety Engineering. He published one SCI Paper in the API Publication.

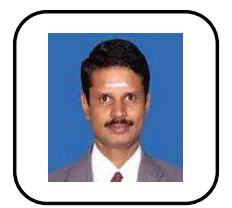

Venkumar $\mathbf{P}$ Working as Senior Professor at Kalasalingam Academy of Research and Education. He contributed more than 10 years in Industrial Engineering domain and published around 39 Research papers.

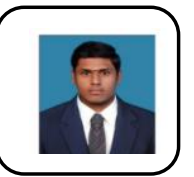

Saravanamani M Pursue his PG Degree in Industrial Safety Engineering at Kalasalingam Academy of Research and Education-Krishnankoil.

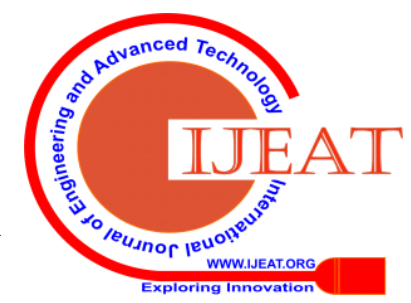

